\title{
Çağdaş Sanatta Kadın Temsilinin İmgesi: Saç
}

\section{A Woman Body Image in Contemporary Art: Hair}

\section{Arzu Parten Altuncu}

Dr. Arş. Gör., Kocaeli Üniversitesi Güzel Sanatlar Fakültesi Heykel Bölümü

e-mail: partenonarzu@gmail.com (DORCID ID: https://orcid.org/0000-0002-7852-8003

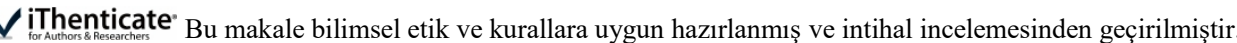

Atıf (APA 6)/To cite this article

Parten Altuncu, A. (2020). Çağdaş sanatta kadın temsilinin imgesi: Saç. Atatürk Üniversitesi Güzel Sanatlar Enstitüsü Dergisi, 26(44), 104116. doi: https://doi.org/10.35247/ataunigsed.677839

Makale Gönderim Tarihi/Received: 20/12/2019

Makale Kabul Tarihi/Accepted: 06/03/2020

Makale Yayın Tarihi/Published: 19/03/2020

Review Article / Derleme Makalesi

$\ddot{O} z$

20. yy ikinci yarısından itibaren, feminist hareket, felsefe ve sanat alanlarında ilerici bir rol üstlenmiş ve geniş bir hareket alanına kavuşmuştur. Kadın bedeninin kadın filozof ve sanatçılarca anlamlarının çoğaltılması, bedene ait olan kavramların sorgulanmasına olanak tanımıștır. Yanı sıra felsefede Deluze, kadın kapasitelerinin önünü açması açısından dikkat çekmekte ve yaratıcı yankıları sanat üretimleri üzerinden izlenmektedir. $\mathrm{Bu}$ düsünsel alt metin üzerine yapılandırılan araștırma, kadın sanatçıların ortaya koydukları performans ve eserlerinde bir imge olarak saçı nasıl ve hangi nedenlerle ele aldıklarının izini sürerek, kadın bedeninin sanatsal anlatım olanaklarına ulaşmayı ve sonuçlarını tartışmayı amaçlamaktadır. Mitolojiden çağdaş sanata uzanan, farklı göstergeleri ile 'saç', metaforik anlam katmanları ile ilgi çekici bir ifade aracına dönüşmekte, zamanlar arasında salınmaya izin vermekte ve böylece kadın bedeninin geçmiş ve bugün arasındaki bilgisini üzerinde taşıyan bir göstergeye dönüşmektedir. Çalışma, Rebecca Horn performansı ile başlayıp, farklı coğrafyalara göc etmis, melez kültürlerinin etkilerini bedenleri üzerinden ele alan Marina Abromoviç, Mona Hatoum ve Nezaket Ekici ile devam etmekte ve saç üzerinden hareket eden sanat üretimlerini içine alarak genişlemektedir.

Anahtar Kelimeler: Çağdaş Sanat, Feminist Süreç, Performans, Beden, Saç

\begin{abstract}
Since the second half of the 20th century, the feminist movement has undertaken a progressive role in the fields of philosophy and art and established a wide range of motion. The multiplication of the meaning of the female body by female philosophers and artists has enabled the questioning of the concepts incidental to body. In the field of philosophy, Deleuze draws attention to it regarding leading up for women's capacities and its creative repercussions are monitored through art productions. The study, which is structured on this intellectual sub text, aims to get through the possibilities of artistic expression of the female body and to discuss its results by tracing how and for what reasons the female artists treat hair as an image in their performance and works. "Hair" which stretches out from mythology to contemporary art, transforms into an interesting means of expression with its different indicators and layers of metaphoric meaning, allowing it to oscillate through times and thus becomes an indicator that bears the knowledge of the female body between past and present. The study begins with the performance of Rebacca Horn and continues with the performances of Marina Abromovic, Mona Hatoum and Nezeket Ekici with the influence of hybrid cultures on their bodies, and expands by incorporating art which are focused on hair
\end{abstract}

Keywords: Contemporary Art, Feminist Process, Performance, Body, Hair

\section{Giriş}

Kadın bakandan daha çok bakılandır. Çünkü bakmak aynı zamanda, düşünmek ele geçirmek, kavramak, tasarlamak gibi bir dizi eylemin de hareket noktasıdır. Bakış ise yüzyıllar boyunca eril hâkimiyetin denetimi altındadır. Kadının bakışının denetlenmesi, aynı zamanda onun dünyasının da denetlenmesi anlamına gelmektedir. Kadın ile dünya arasında perdelenen kısıtlı bakış, kadın ile kadın bedeninin arasını da açar. Kadının bedenine olan bakışı bu noktada yaralıdır. Pek çok kadın sanatçının, kendi bedenleri üzerinden hareket noktası oluşturmalarının önemli sebeplerinden biri de budur. Kadın, farklı alanlarda kendini ifade edilebilme olanaklarını, fazladan gösterdiği mücadeleler sonucunda elde edebilmiştir. Kadın bedeni ve aklı, izana ancak erkek ile gelebilmiş ve doğal olarak, kadının yaşamı, erkek tarafından belirlenen, kısıtlı alan ve olanaklar içerisinde domestik faaliyetler ile örüntülü bir dünyanın içinde sürdürülmüştür. Ataerkil toplum düzenine geçişle başlayan bu süreç, günümüz dünyasında farklı coğrafyalarda çeşitli etkilerini, sürdürmekle birlikte geçtiğimiz yüzyılın ikinci yarısından itibaren kadın dünyası önemli ve geniş yayılımlı kazanımlar elde etmiş, bu açıdan pek çok farklı kesime ilham kaynağı olmuştur.

Bugün yaşanılan kazanımların zemini ve geleneksel ataerkil düzenin katı yapısı, özellikle sanayi devrimi ile birlikte, ucuz işgücüne ve iki dünya savaşı sırasında kadına hemen her alanda duyulan ihtiyaçlar doğrultusunda çözülmeye başlamıştır. Bugün elde edilen kazanımlar noktasında belirtilen dönemler önemli bir sıçrama alanı olarak kabul edilmektedir. Savaş, kadın üzerine sonsuz kötü etkilerini yaşatırken, dışarda hayatın içinde, üretimin merkezinde olma durumunun deneyimlenmesinin önünü açmış ve bu paradoks, kadını günlük yaşam pratiklerinin dışına taşımıştır. 
Çalışmanın, ilk bölümünde özellikle II. Dünya Savaşı sonrası etkilerini genişleten feminist teorinin sanat üretimlerine kazandırdığı düşünsel alt yapı ve Deleuze felsefesinin hem düşünce kavramını etkilemesi hem de feminist teoriye açmış olduğu hareket alanları üzerinde durulmaktadır. Ardından çeşitli mitolojilerden elde edilen referanslar doğrultusunda kadın bedeninin bir göstergesi olarak saçın tarihsel süreçleri çeşitli alanlardan gösterilen örnekler ile açıklanmaktadır. Son olarak elde edilen bilgiler ışığında çağdaş sanat içerisinde kadın sanatçıların, kadın bedeni ile kurmuş oldukları ilişkiler saç üzerinden farklı dönem sanatçıların ortaya koydukları üretimler üzerinden açıklamaktadır. Rebeca Horn ile başlayan sanatçı seçkisi, Marina Abromoviç, Mona Hatoum, Nezaket Ekici, Khadjia Baker ve Gamze Öztürk 'ün saç ve beden ilişkisi üzerine gerçekleştirdikleri performanslardan oluşan bir seçki üzerinden örneklendirilmektedir.

\section{Yöntem}

Konunun çok yönlü biçimde ortaya konulması açısından, betimleyici yöntem kullanılmıştır. Feminizmin yaratmış olduğu olanaklar doğrultusunda, kadın bedeninin sanatsal ifadelerini, saç üzerine gerçekleştirdikleri performanslar ile ortaya koyan; beden, cinsiyet, politika konularına açılan, örneklerin elde edilmesinde, görsel kayıtların ve yazılı dokümanların toplanması, kitap sergi katalogları, performansların görsel kayıtları, performans ve sergi izlenimleri ile sağlanmıştır.

\section{Feminist Teori Bağlamında Kadın Bedenine Yaklaşımlar}

Kadın bedeni doğanın devamlılığını sağlaması açısından mitsel bir önemle çağlar boyu övülürken, gerçekte bu beden doğayla özdeş, kültürel yaşamdan ise mütemadiyen dişlanmıştır (Gatens, 2018, s. 100). "Kadın denen yaratığı, üreten şey doğa değil, bütünüyle uygarlıktır" (Direk, 2009, s. 12) tespitinde bulunan, Simone de Beauvoir, 'İkinci Cinsiyet' kitabı ile kadınlığın özel durumunu düşün dünyasında ayrıcalıklı bir alan açarak ortaya koymaktadır. Burada Hegel'in kişiliğin öz bilincin ortaya çıkmasında bir başka bilinçle ilişkide olma durumu ile ortaya konulan ve içerisinde dönüşme imkânı barındıran iktidar ilişkisi, Beauvoir tarafından kadınlık durumu açısından reddedilir. Kadın, erkek karşısında, mutlak bir başka olarak inşa edilmiştir ve bu başkalığın kökleri ise anatanrıçaya yani ataerkil dönem öncesine dayanmaktadır. Ataerkil düzen içerisinde kadın bir köle değil ancak ebedi dişi miti olarak tanımlanır. Erkek benzerini köleleştirirken, kadını diyalektiğin olabilecek ihtimallerinin dıșına atarak mutlak bir başka yaratmıștır. İște tam bu noktada kadın, erkeğin hizmetkârıdır (Direk, 2009, s. 1419). 1929 yılında, Virginia Woolf'tan gelen çağrı yerini bulmakta, kendilerine ait bir odadan, düşüncelerini, seslerini, sözlerini yazan kadın yazarlar ve sanatçılar felsefede de yeni anlamlar ve farklı okumalar ortaya koymaktadır. İlk kuşak feministlerin politik olarak varlık göstermek ve oy hakkı talep etmek için Fransız İhtilaline uzanan, yurttaş olarak tanımlanma isteği karşısında; bedeni kafasından giyotinle ayrılan Olympe de Gouges ile başlayan süreç, I. Dünya Savaşı sonlarında kazanımlar elde etmeyi başarmıştır. Yurttaş olmuş olan kadınlar bu kez bedenlerini ele geçirme mücadeleleri ile yeni bir politik alanda farklı kadın olma durumlarını tartışmaktadır.

20. Yüzyılın ilk yarısında kadınlar verdikleri mücadele içerisinde, seçimleri doğrultusunda, keskin ve görece dışlanmış hayatları, savaşlar ile birlikte aşılmakta, kadın yaşamdaki varlık alanlarını genişletmektedir. Ancak II. Dünya Savaşı sonrası eve dönen erkekler ile birlikte yürütülen devlet politikaları, kültür endüstrisinin telkinleri ile kadın, domestik hayata özendirilmektedir. Ev içerisinde, sürekli güzel bir beden arzusu içerisinde tutulan kadın, pazarın geniş bir tüketicisi olarak hedefte tutulurken, savaşın dışarıya çıkardığı kadınlar, tersine bir hareketle tekrar ev içlerine yönlendirilecektir. Reklam sektöründen, filmlere; güçlü ve hayatı bilen ama evde olmayı tercih eden bu kadınlar, politik olarak demokratik hayata katılmakta, eğitimlerini tamamlamakta ama kendi bedenlerine dair olan kavram ve karar alanına erişememektedir. İkinci dalga feministlerin arasında yer alan, Simone de Beauvoir ve ardından gelen Shulamith Firestone, kadınların özgürleştirici bir rol oynaması açısından, kadının doğurganlığını ve ona bu yönde addedilen değerleri reddetmektedir. Aynı dönemde gelişen karşıt görüşlü feministler ise doğurgan kadın bedeni ile üretken düşünce arasında pozitif yönde etkiler olduğunu savunmaktadırlar. Her iki görüşün gerçekleşmesinin ortak koşulu ise, kadının kendini var etmek adına fazladan mücadele vermeyi göze almasıdır.

1960 sonrası dünyada yaşanılan politik gelişmeler ile birlikte feminist hareket radikalleşmekte, özgürlük politikaları bağlamında, farklı topluluklarca desteklenmektedir. Kadın bedeni, kadın sanatçıların üretim mekânına dönüşürken, bedeninin, farklılıkların altı çizilmekte bunlarla birlikte sanatta olagelmiş kadın teslimiyetlerini zedelemekte, alışılışmış bakışı değiştirmektedir. İzleyiciyi bedene çeken ve kışkırtan bu üretimler, Simone de Beauvoir'ın kadın bedenini “etobur bir bataklık” (Berktay, 2009, s. 59) olarak tanımlamasını anımsatır, izleyicinin çekildiği bu beden, kuşkusuz tekinsiz bir mekândır. Eleanor Antin ideal bir beden ölçüsüne ulaşmak için yaptığ rejimi fotoğraflamakta, Yoko Ono; elbiselerini izleyiciler tarafindan kesilmesini olası kılmaktadır. Valie Export; bedenini sokakta rasgele karşılaştı̆̆ı insanların dokunmasına açmakta, Faith Wilding, ' Bekleyiş’ isimli performansı ile kadının geleneksel yaşam içerisinde edilgen rollerini, sessiz bir mırıltıyla biteviye sıralamakta, Gina Pane 'Ruh Hali' performansında bedenini kanatarak, yaralayarak, kadın bedenine yöneltilen şiddeti, kendi bedeni üzerinden ortaya koymaktadır. Amerikalı Feminist sanat tarihçi, Linda Nocklin, 'Neden Büyük Kadın Sanatçı Yok?' başlıklı sarsıcı soruyla başlayan makalesinde, eril tarihi sorgularken, temel sorunların başında, kadın anlamlarının teoriden uzak bırakılmasını, düşünen özne olarak görülmeyen kadının, sonsuz tekrarla sanatın nesnesi 
olmasını hatırlatmaktadır. 1974 yılında Judy Chicago, geniş sayıda kadın sanatçının katılımıyla oluşan 'Yemek Daveti' isimli kolektif çalışması ile tarihte yok sayılan pek çok kadın sanatçıyı gündeme taşımıştır (Antmen, 2010, s. 239-250). Toplumsal cinsiyet üzerinden kadın bedenine yapılan eklemeler, farklı disiplinlerce ortaya konulmakta eleştirilmekte ve değiştirilmesi yönünde yoğun çabalar gösterilmektedir.

1980'li yıllarda Feminist teoride Foucault'nun beden çözümlemeleri etkili olmuştur. Kadın ve erkek üzerinden süren cinsel farklılığa dayanan tartışmaların ekseni beden ve iktidar kavramları üzerinden genișlemiștir. Foucault, mikropolitik iktidar uygulamalarının sosyal açıdan uygun bedenler sağladığını tarihsel açıdan ortaya koymakta ve imgesel beden içerisinde toplumsal ve tarihi açıdan özel eylemlerin etkileri genetikle değil, iktidarla ortaya çıkmaktadır. Beden bu anlamda cinsiyetçi bir yaklaşımla çözümlenebilecek alandan daha fazlasına ihtiyaç duymakta, toplumsal açıdan ayrıcalıklı ya da yoksun olma durumları ile ele alınmaktadır. Bedensel durumlar açısından çeşitlenen bu farklılık, mücadele alanlarını da o ölçüde çeşitlendirecektir (Gatens, 2001, s. 69-75). Bu ataerkil düzene yönelen ve her yöneldiğinde onu besleme tehlikesini de içinde barındıran olumsuzlamanın tehlikelerinin tartışıldığı, feminist kuramcılar tarafından önemli bir bakış kazandırmakla birlikte asıl vurgu, olumlayıcı bir düşünce elde edilebilme olanaklarının yakalandığı Deleuze felsefesi ile hız almakta, katlanarak çoğalma imkânlarını taşımaktadır (Chanter, 2009, s. 108-109). Modern Düşüncenin mihenk taşı Descartes, akıl ile bedeni birbirinden ayıkırken, erkeği; akıl, düşünce, kültürle özdeş kılmaktadır. Akıldan ayrı tutulan beden ise, doğa, tutku ve nesne ile yan yana görülmekte ve kadın burada konumlandırılmaktadır. Modern öznenin temellendiği Kartezyen düşüncesi içinde; kavramsallaştırılmış olan düşümce sistemlerinin tutarlı, özsel bir doğaya sahip olan düşünce biçimi, Delueze için sorunludur, kısıtlayıcıdır ve bu sebepten, 'durağan' özdeşlik yerine 'oluş' düşünce sistemini önermektedir. Deleuze düşünce imgesini aktarırken, güçlü metaforlardan yararlanmakta, akış halinde ve hiçbir zaman durağan olmayan kavramlar, bir problemden diğerine geçişte, değişim ve dönüşüm yaşamaktadırlar. Bir şemaya göre yükselen ve ağaç imgesi ile felsefede aktarılan durumun yerine, köksap imgesini ortaya koyar, bu köksaplar her noktayı, bir başka noktaya bağlar ve soy kütük karşıtıdırlar (Chanter, 2009, s. 120). Oluş düşünce sisteminin açıklanması için molar ve moleküler arasındaki ayırım ve majör minör kavramları ile kesişme noktalarına bakılması gereklidir. Sabit, içine çökmüş bir kütle, kendisinden önce, kavramsallaştırılmış olan düşünme biçimini Delueze felsefesinde 'molar' varlıklar olarak karşılık bulur ve bunlar bilim veya alışkanlıklar sayesinde tanımladığımız, özne nesne ya da biçimlerdir. "Oysa moleküler olan, bir kimliğin içinde katılaşmış değildir; hareketli ve değişken bir moleküler kolektife olarak kalır. Oluşun amacı moların altını oymak ve moleküler hale getirmektir: minöriterliğe imkân tanıyan bir hareket, firar yolu ve ya 'kaçış çizgi 'bulmaktır (Stark, 2018, s. 48). Çoklu, heterojen, düzenli kalıpları kılan ve disiplinleri aşındıran, problemlerin çözüme ulaştığ değil, problemlerle çözümler arasında yaratıcı bir düşünce sistemi olarak ortaya çıkmaktadır. Düşünceyi karşılaşmalar ve şoklara dayanan sonsuz bir iş olarak tanımlayan Delueze, düşüncenin belirli bedenlere bağlı olduğu ön kabulünü de kırmakta ve düşünceyi, fallus merkezli sisteminin ötesine geçmesini sağlamaktadır(Stark, 2018, s. 37-39). "Minörden daha majör, daha devrimci bir şey yoktur" (Stark, 2018, s. 43). Kadın minördür ve oluş düşüncesine daha yakındır. Ancak bu minörite, kadına bedeninden değil, Ataerkil bir düzen içerisinde konumlandırılan durumundan dolayı addedilir. Bu sebeptendir ki, minör oluşu kadın bedenine sabitleyerek Deleuze'ün beden algısını çözümlemek yanıltıcı olur, "bütün oluşlar hem erkek, hem de kadın oluşlar olarak, öncelikle kadın -oluştan geçmelidir" (Stark, 2018, s. 44). Feminist teorisyenlerin bu 'kadın oluş' kavramından yola çıkarak, sıçrama alanları yarattığını görmekteyiz. 'Erkeğin ağacının bir dalından başka, Çoğunluk Yasası'na tabi bir terimden başka, oluş arzusunun yolunu açmaktaki başarısını tanırlar" (Chanter, 2009, s. 121). Deleueze felsefesinin, feminist teoriye doğrudan bir katkı sağlamasından çok, düşünce biçimine olan sarsıcı yaklaşımı, Batı Felsefesine olan itirazları ve kadın oluş kavramları açısından son dönem feminist teorisyenlerce ilgi görmekte, feminizme olan katkısının kabulü ya da reddine açılan tartışmalar ise kendi başına dinamik bir süreç haline dönüşmektedir. Bunun yanında Deleuze felsefesi 'fark' kavramını öne çıkaran ve olumlayan bir sisteme dayanır. Aynı olan ya da tanınan şeyler, düşünce akışını sınırlayan bir durumu ortaya çıkarmakta, oysa feminizmin 'farklar' üzerinden geliştirdiği teori ve gelişen yeni problemleri ile bu düşünce sistemine göre içinde pek çok kıvılcım taşımaktadır.

\section{Saç ve Mit}

Saç follikülü, hem erkek hem kadın bedeninde bulunmakla birlikte, kadın bedeninin başı örten kısmında erkeğe göre bu follikürlerinin daha sağlam ve daha sık olduğu bilinen, daha da ötesi görünen bir gerçektir. " Tarih öncesine ve tarihsel dönemlere ilişkin görsel ve yazılı belgeleri okuduğumuzda, dünyamızda en az otuz bin yıl boyunca kadın gövdesinin ve saçının büyüyle olağanüstü güçlerle ilişkilendirildiğini ve onlarla birlikte ortaya çıkan fenomenlerin sürdüğünü anlıyoruz" (Cıbıroğlu, 2017, s. 22). Kadının saçı aynı zamanda onun başını, iktidarını, vajina ve doğurganlığını anımsatır. Kadının saçı ve vajinası, primitif dönemde; içine alan, saklayan ve yutan tekinsiz bir alan olarak algılanır. Bu imgeler değişerek, dönüşerek halk türkülerinden, şiire, edebiyattan plastik sanatlara, tek tanrılı dinlerin kimi ritüellerinde, felsefe ve psikanaliz gibi farklı disiplinlerde etkilerini göstermektedir. Karşımıza çıkan bu imgeler, insanlık tarihinin hafızasında yer etmiş ve günümüze taşınan, canlılı̆̆ını koruyan izlerdir. 
Batı Mitolojisinde insanların kader tanrıçaları olan Moiralar, bir inanışa göre Zeus'un diğer inanışa göre gecenin kızlarıdır (Grimal, 1997, s. 513). Ancak ister Zeus'un, isterse gecenin kızları olduğuna inanılsın, Moiralar soğuk ve ölümü çağrıştırmaktadır. Çünkü inanışa göre insan, ana karnından doğar doğmaz kader onun ömür ipliğini bükmeye koyulur (Erhat, 1996, s. 384). Moiralar üç kız kardeş olup; biri doğumla birlikte ömür ipliğini eğirirken, diğeri ipliği yumak yapıp sarmakta, ötekisi ise ölüm anı gelip çatınca, kişinin yaşam ipini kesmektedir. Burada ipin bedenle olan bağlantısı, göbek bağının kesilmesine benzer bir şekilde kurgulanması, beden, ip ve saç kavramlarını birbirine yakınlaştırmaktadır. İp, bu üç kız kardeş mitosunda olduğu gibi, kadına dair olan bir dünyanın önemli göstergelerinden, önemli kadın bilgilerinden birisidir. Bu çağrışımlar, dünyanın ilk inanç merkezi olarak bilinen Neolitik dönem Göbeklitepe kazılarında ortaya çıkan, doğum esnasında kadın bebek ve göbek kordonunu betimleyen bir kaya resminde yer almaktadır(Görsel 1).

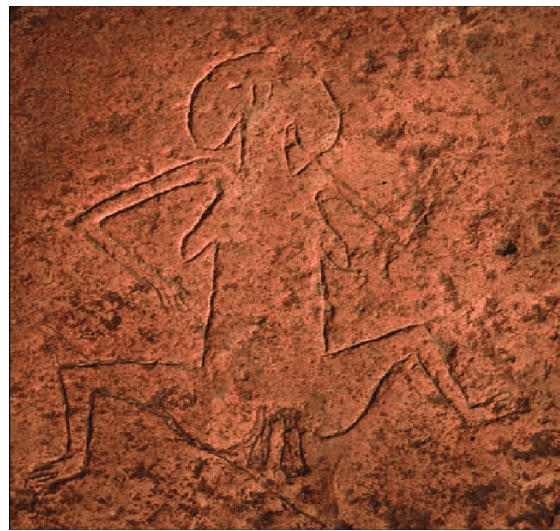

Görsel 1. Doğum yapan kadın, M.Ö. 8.000-12-0000, Göbeklitepe, Şanlıurfa, Türkiye

Bu imge örüntülerine dair, bir diğer kaya resmi, Anadolu Çatalhöyük'te bir elinde yılan diğer elinde ip bulunan ve stilize edilmiş saçları ile dikkat çeken kadın figürüdür; resim primitif dönemde; saç, yılan ve iplik bağlantıları üzerine önemli bir temsil olup, M.Ö 5600 tarihine değin uzanmaktadır (Cıbırlıŏglu, 2017). İplik, primitif dönemden bu yana kadının bilgisindedir ve bu bilgiyi üretip geliştirebilmesinin avantajlarını yaşamış olan kadın, ipliği düğümleyerek, eğerek, örerek, o dünyanın içinde bir üst konuma çıkarılmıştır. Evcilleştirilmek üzere yakalanan hayvanların boynuna ipi tanrıçaların geçirdiğine dair olan betimlemelerden de anlaşılacağı üzere ip bir güç sembolüdür. Evcilleştirilmek üzere seçilip gösterilen hayvanlar erkektir. Bir dişi tanrı tarafından erkek hayvana ip atılması aynı zamanda onun gücünü kontrol altına alındığının simgesel bir göstergesidir. Kadının doğaüstü güçlerinin sembolleri arasında bulunan ip ve saç sıklıkla göze getirilmekte ve bu güçler eril cinsin korkularını beslemektedir. Anadolu bu tür sembollerin günümüze ulaştığı özel ve bereketli topraklar olmasının yanında konunun araştırılması için zengin semboller de barındırmaktadır (Cıbıroğlu, 2017, s. 124-130). Batı ve Anadolu mitolojisinde, saç üzerine en dikkat çekici figürlerin başında ise canavar kız kardeşler olarak bilinen Gorgalar ve Medusa gelmektedir. Geceyle gündüzün eşiğinde oturan, tunç elleri, altın kanatları, alınlarında yaban domuzu dişleri ve her yöne dağılıp, nerden geleceği belli olmayan yılan saçları ile kurbanlarını kavrayan bu canavarların, saçlarının tek perçemi saldırgan orduları dize getirmeye yetmektedir (Grimal, 1997, s. 218). Bu canavar kardeşlerden sadece Medusa ölümlüdür ve mitolojide Perseus'un türlü maceraları göze alıp, Medusa'yı yenmesi üstüne anlatılan mitosta geniş yer bulur (Erhat, 1996, s. 1101). Ancak Medusa miti, Helen kültüründe değişime uğrar, saçlarının güzelliğiyle dillere destan olan bir kıza dönüşür. Athena'nın kıskançlığı sonrasında cezalandırılır ve saçının her bir teli yılana dönüştürülür. İki mit, iki farklı kadınlık durumuna yönelmektedir. Batı'nın karşısında Antik dünyada önemli bir doğu temsili olarak karşımıza çıkan, Yahudi inancı içerisinde Tevrat'ta İsraillilerin kurtarıcısı sayılan Samson, bir parmağı ile tapınak sütunlarını deviren ya da tek başına bin kişiyi öldürebilen müthiş gücünü, Yehova'dan almış olduğuna inanılır. İnanışa göre, Samson'un saçı usturaya değerse bu gücü kaybolacaktır. Pagan kraliçe Delila kendine âşık ettiği ve dizinde uyuttuğu Samson'un saçını kestirir ve bu yolla kahramanın ölmesi mümkün hale gelir (Cıbıroğlu, 2017, s. 181).

Saçın bilgisini ele geçirmek gücü kuvveti de ele geçirmektir ve bu bilgi kadın dünyasının hiç de yabancısı olmadığ kadının saçı, kocasının evine gittiğinde kesilmektedir. Bu, bir başka dünyanın içinde, başkaca sorumluluklar yükleneceği yeni bir hayatın hatırlatılması, gelinin evlilik öncesi olan hayatı ile bağlarının koparılmasının görsel bir ifadesidir. Anadolu'nun pek çok yerinde evlenen kız bakire değilse baba evine saçları kesilip gönderilmektedir (Cıbıroğlu, 2017, s. 183). Saç ve akıl bir anılır, birinin değişimi diğer öbürünün dönüşümüne yol açacağına inanılır. Erken Hıristiyan dönemine gelindiğinde ise, kadınların erkek gibi saçlarını kestirmelerinden ötürü, aforoz edilme tehlikesi ile karşılaştıkları görülmektedir (Güzel, 2018, s. 103). Saç kadının doğal betimlemesi, onun doğasının bir yansımadır. Artık kadın ne tapınılan ne de doğurmasından ötürü tanrılaştırılan bir varlıktır. Günahkâr bir vücutla doğurduğuna inanılan bebeği, kutsal vaftiz törenleri ile arındıracak, fazladan bildikleri ya da önsezileri dolayısıyla 
cadı olarak tanımlanıp cezalandırılacaktır. Bunun yanında kadının, erdem ve iffeti yüceltilecektir. Saç bu erdemin timsali olarak semavi dinlerde uzatılacak, örtülecek ya da kapatılacak güçlü bir politik alana dönüşmektedir. 11.yüzyıl Ortaçağ mitinde, Anglosakson bir karakter olarak karşımıza çıkan Laydi Godiva oldukça sıra dışı bir kadın kahraman durumunu temsil etmektedir. Zamanla değişen hikâyesinin temelinde kocası Lord Leofric'den, Coventry halkının köle ve esirlerinin özgürleşmesini talep etmesi üzerine gelişir. Bu zengin ve soylu kadın, köle ve çaresiz insanları anlamıs onlara acımış ve yardım etmek için elinden geleni yapmaya çalıșmaktadır. Godiva'nın 1srarları ve bu işe yanaşmayan kocası, halkın üzerindeki gücünün devam edebilmesi için karısına olmayacak bir teklif sunar. Ancak çıplak bir şekilde kentte dolaşması şartıyla taleplerini yerine getireceğini dile getirir. Godiva, ayak topuklarına değen uzun saçları ile vücudunu örterek, at üstünde kenti bir boydan bir boya çıplak, halde gezer. Saç onun çıplaklığını görünmez kılan, kadının iffetini koruyan onu kötülüklerden yalıtan bir araca dönüşmüştür. Saç kadının gücünün önemli bir sembolüdür (Gillespie, 2006, s. 2-26). Anadolu mit ve masallarında Sarı Kız efsanesi, geniş bir coğrafyada etkilidir. Al basma gibi cinler üzerinde de hükmü geçen ve ormanlarda su kenarlarında yaşadığına inanılan bu efsanede, kızın saçının bir tutamına sahip olan, şifa bulup güç topladığına inanılır (Beydili, 2005, s. 487). İngiltere'de çok sevilen halk masalında, sevgilisinden ayrılması için kuleye kapatılan kız, uzun ve gür saçlarını kuleden aşağıya sarkıtarak sevgilisinin tırmanmasını sağlar. İki sevgili Rapunzel'in saçları sayesinde birbirlerine kavuşur (Cıbıroğlu, 2017, s. 27). Erkek dünyasında bulunmanın ve varlık göstermenin koşullarından biri de kadının saçlarından feragat edilmesi olarak simgeleşmiştir. Örneğin Jan Dark böylesi bir duruma karşılık gelmektedir. Saçlarından feragat edip savaşmış, ardından engizisyon tarafından erkek kılığına girdiği için cezalandırılmış bir halk kadın kahramanıdır. Lamartine'nin romantik akımın ünlü eseri ve roman kahramanın da ismi olan, Greziella; ölüm döşeğindeyken saçlarını keserek sevgilisine gönderir. Romanın geniş bölümünde Grezialla'nın güzelliği, hayattan kaçışı, hastalığı ve masumiyeti, eserde güçlü bir simge olan genç kızın saçları üzerinden aktarılmıştır. Saç, kadının en masum ve en güzel aksesuarıdır. Grezialla, Fransa'da devrim hareketlerinin ve İngiltere'de Viktoria döneminin etkili olduğu bir dünyanın içerisinde yazılmıştır. Bu dönem kadınlarının imajı, şiirsel romantik kırılgan ve uzun saçlıdır. 19.Yüzyıl dünyası kadından bir masal kahramanı güzelliği beklerken, 20. Yüzyılın çöken imparatorlukları, I. Dünya Savaşı, teknolojide yaşanılan gelişmeler, iş gücüne dayalı göç, giderek kozmopolit hale gelen kentlerin yeni kültürel dünyasında, kadın artık masalın içinden çıkmış, bizzat kendi tarihini yazmak için dışardadır. I. Dünya Savaşı öncesi Fransa ve özelinde Paris’te, kamusal alan içinde kadın davranışlarının ve kıyafetlerinin bir dönüşümü söz konusudur. 1910 yılında Fransız aktris Polaire ve dansçı Irena Castle, Bob model kestirdikleri kısa saçları ile yeni bir moda akımı oluşturmuşlardır. Bunun yanında Coco Chanel, Jeanne Lanvin gibi kadın modacılar, kadın bedeninin, günlük yaşam içerisinde rahat edebileceği kıyafet kesimleri ve kumaş seçimleri ile kadın bedeninin fazladan yüklerinden onları kurtarır (Koç, 2018, s. 876). İlk kuşak Feminist hareketlerinin etkisi ve kadınların saçlarının bu kısa boyları yeni bir kadınlık durumunun görsel ifadesi olmaktadır. Kadın, kendi bedeninin ifade ve kavramlarını, kendi inşa etmiş olduğu imajının üzerinden aktarmaya, sözlerinin suretini yansıtmaya ve hemen her dönem olduğu gibi, erkekler tarafından tepki görmeye ve bu sefer kısa saçları için mücadele etmeye başlamıştır. Kadın politikalarının, kavramlarının ve sanatının bedenleri üzerinden birer mücadele alanına dönüştüğü dünyalarında, her dönem önemli ve güçlü bir hafiza simgesi olarak saç, çağdaş sanat üretimlerinde bedenin bir temsili olacaktır.

\section{5. Çağdaş Sanatta İmge Olarak Saç}

Kadın sanatçılar, kadın bedeninin düşünsel sınırlarını genişletmek, felsefede kadın anlamlarını üretebilmek, farklı kavramlarla, kadın bedeni üzerine yeni okumalar gerçekleştirebilmenin olasılıkları üzerinde çalışırken, ortaya koymuş oldukları sanat üretimlerinde bedensel imge ve performanslara yönelmiş olmaları doğal bir sonuç olarak karşımıza çıkmaktadır. Hemen hemen tüm bir sanat tarihinin kadın bedeni üzerine yoğunlaşan bakışının kırılması ve eril anlamların oluşturduğu sınırlar içerisinde gezinen kadın bedenlerinin sarsılması için, kadın sanatçıların bedenleri üzerinden bir hareket noktası belirlemiş oldukları görülmektedir. Kadın bedeni, politik ve kültürel pek çok anlamla yüklüdür. Eril dünyanın kadın bedeni üzerinden üretmiş olduğu eklektik kültürün yanında, sanatın kendi içerisinde sanat piyasasıyla giriştiği mücadelede bir çıkış yolu olarak beden önemli bir temsil ve önemli bir mekân gücüne sahiptir. Özgürlük politikalarından kazanmış olduğu ivmeyle, sınırsız bir dünya söylemini geliştirirken, sanatçı kendi bedenine çekilmekteydi. Çünkü beden, bağımsız olma kabiliyetini arttırmanın yanında bir ve biriciktir. Kadınlar, politikalar, tarih ve felsefenin çağlar boyu kısıtlayıcı etkilerini hem üzerlerinde taşıyor hem de sanat aracılığıyla bedenleri üzerinden bu bilgilere itirazlar geliştirme imkânlarını araştırıyor ve oluşturabiliyordu. Kadın sanatçılar bedenlerinin sınırlarını sanatsal eylemler üzerinden keşfe çıkarken beden; etkili, şiddetli ifadeler gerçekleştirecekleri bir alana doğru açllıyordu. Tam bu noktada, bedenin bir parçası olarak 'saç', kadın temsilleri açısından güçlü bir simge olarak ele alınmakta ve yeni anlamlar üretilmesi konusunda elverişli bir imge olarak karşımıza çıkmaktadır.

1974 yılında Rebacca Horn 'Egzersiz 8: İki Makasla Aynı Anda Saçları Kesme' isimli performans ve video çalışmasında, kadına yüklenen rollerden sıyrılma, kadınlığın altını oyma ve onu katı normlardan çıkarmak adına üretmiş olduğu eserinde, toplumsal baskının kadın üzerinde yaratmış olduğu ağırlığın bedenden sökülüp atılmasını, saç imgesi üzerinden aktarmaktadır. Eser, aktör Otto Sander'in yılan dansı ya da yılan savaşı olarak adlandırılan ve yılanların çiftleşme ritüellerini konu alan bir epizot aktarımı ile başlamaktadır. Ardından kamera 
Horn'a odaklanmakta ve sanatçının her iki elini kullanarak, sivri makaslarla saçını kesme eylemi gösterilmektedir. Simetrik olarak, bir birine uyumlu bir şekilde kesmeye çalıştığı saçları giderek kısalmakta, makasların keskin hareketi ve açılıp kapanan ağızları, Sander'in aktardığı yılan ritüellerini hatırlatmaktadır (Görsel 2). Horn, kadın saçının alışıldık boyunu geçen bir kısa saça ulaştığında, ellerindeki makaslarla, bakışlarındaki tehditkâr ifadeyi, kameraya yönlendirir. Ardından, görüntü çift pencere önünde duran çift boy aynası ile boş bir evin içerisine odaklanmakta ve yan yana uyuyan iki sevgiliyi konu alan kısa bir şiirin görüntü üzerine akan yazıları ile sonlanmaktadır (Ravaglia, 2016). Bu şiir, bir aşk hikâyesinin sonu olabileceği gibi, başı da olabilecek bir durumun habercisi olarak algılanmaya açıktır. Saç kesme eylemi kadın dünyasında farklı anlamlara doğru açılır; bir anlamda zamanın sayacını sıfırlamaya yaramaktadır. Kesilen saç, ardında yeni bir hayata geçişin sembolü olmakta, saçın kısalmış hali ile yeniden uzaması süreci arasındaki zaman farkındalığı arttırmaktadır. Saç kadın bedeninin zamanıdır.

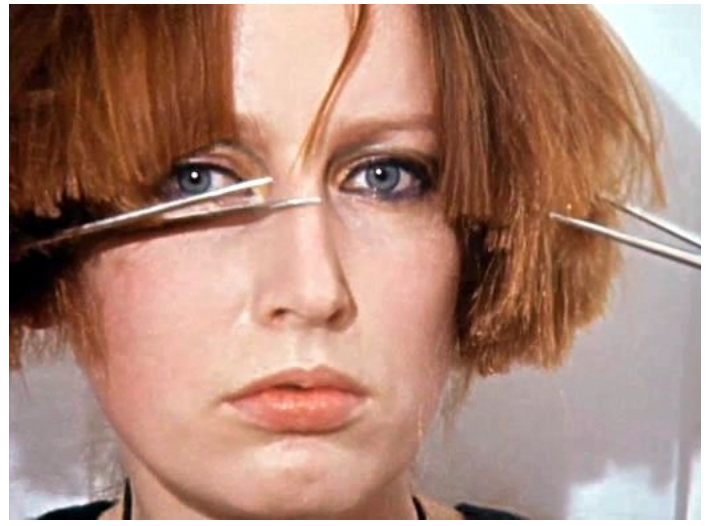

Görsel 2. Rebecca Horn, İki Makasla Aynı Anda Saçları Kesme, 1974

Kadın Performansları alanında uygulayıcı ve teorisyen olarak öncü bir isim olan Judy Chicago resim ve heykelin tersine performansın öfkeyle ateşlenebilir olma özelliğine dikkat çekiyordu (Carlson, 2013, s. 221). Öfkesini acıyla bedeninde öğüten, acıyı meditatif bir öğe olarak kullanan Marina Abromovic, başka bir coğrafyanın bilgi ve deneyimlerini taşıdığı bedeni üzerinden, 1960'li yılların sonundan itibaren sarsıcı performanslarını ortaya koymaya başlamıştı. 2015 yılında gerçekleştirdiği konuşması sırasında sanatçı performansı, belli bir zamanda, belli bir yerde seyirci önünde yapılan fiziksel ve zihinsel bir kurgu olarak tanımlarken, izleyicisi ile sanatçısı arasında bir enerji diyaloğu üzerinde durmaktadır (Abramovic, 2015). Ancak, kimi zaman ölümle sonuçlanması da mümkün halde olan performanslarının etkisi gerçekte çok katmanlı bir durumdadır. Hem Abromoviç'in kendi sınırını tekrar tekrar inşa etmesi, hem de izleyicinin muğlaklaşan konumu performansları çok bilinmeyenli bir denklem haline dönüştürmektedir. Özellikle ilk dönem performanslarında şiddet unsuru ucu açık bir halde bırakılmaktadır. Resim disiplini içerisinde üretim gösteren sanatçı 1960‘ların sonunda performansa yönelmesi ile sanata olan bakışı kökten değişmiştir. 1975 yılında Abromovic'in 'Sanat Güzel Olmalı, Sanatçı Güzel Olmalı' adlı performansı, kadınlık durumu ve bu durumun sanattaki yansımalarını, eril kodlamaların baskısıyla oluşan beklentilerin, kadın bedeni üzerinde yaratmış olduğu tahribatlar üzerine yoğunlaştığı, ilk dönem çalışmalarından biridir (Görsel 3). Abromovic'in çıplak halde gerçekleştirdiği performansında, kadının sanattaki çıplaklığı ile eril beğeninin tatminine sunulan bağ kırılmaya çalışılmaktadır. Ortada ne heykel ne de resim aracılığı olmadan, gerçekliği göz önüne alabildiğince sunulan bir çıplak kadın vardır. Ancak bu çıplak beden, izleyicisine bakışını teslim etmiş bir çıplaklık değildir. Çıplaklığın dışında bir bilgi barındırdığından, bakışla ele geçirilebilecek bir beden de değildir. Abromovic'in bir elinde saç firçası diğer elinde tarakla başlayan, gündelik bir rutin olan saçlarını tarama eylemi giderek şiddetlenen bir duruma dönüşür. Saçlarından yüzüne yönelen tarak ve firça hareketleri ile Abromovic; yolarak, kafasına vurarak ve yüzüne yayılan darbeler boyunca, atonel bir ritimde kendisine sürekli 'sanat güzel olmalı, sanatçı güzel olmalı' emir kipini tekrarlamakta, kendini ikna etmeye, uyum sağlamaya yöneltmektedir. Abromovic, güzel olmaya çalıştıkça, zorlanmakta ve durumundan bir türlü tatmin olmayan bir histeri nöbetine benzer tepkiler geliștiren hareketleri üzerinden acı ve neşenin yer değiştirdiği, bu iki durumun silikleştiği, tanımsız bir alandan yeni bir ifade ortaya koymaktadır. Beden sarsıcı ve tedirgin edici ve acı çektiği anlaşılır bir hal almıştır. Şiddet ve acı kadın bedeninin tanıdık olduğu kavramlardır. Sanatın içinde güzele karşılık gelen kadın, yaşamında edilgen bir konumda, kendisine yüklenen pek çok kadınlık halinden yorgun ve büyük baskı altındadır. 


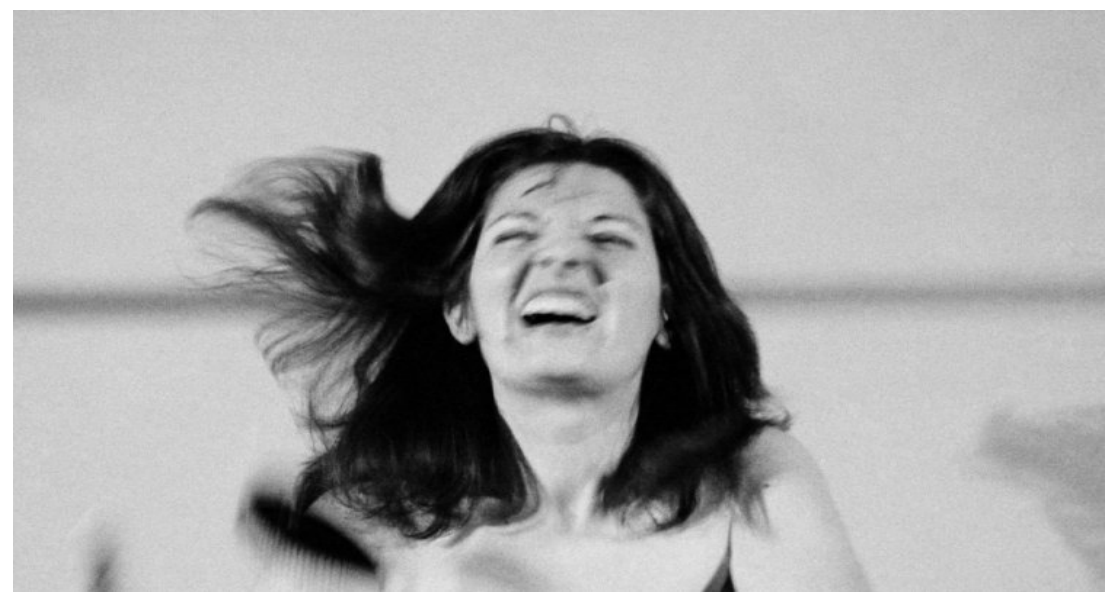

Görsel 3. Marina Abromovic, Sanat Güzel Olmalı/ Sanatçı Güzel Olmalı, 1975

Marina Abromovic'in 1976 'da yolları Alman sanatçı Ulay ile kesişir ve on yılı aşan bir süre ortak performanslar sergilerler. Bu dönem performansları arasında eril/dişi kodlamalarını, sanatçı ve ego durumlarını kendi bedenleri ve sınırları üzerinden deneyimledikleri performansları geniş ilgi görür. Birbirlerine bakarak, iterek, vurarak, dokunarak, bağırarak uzun zamana yaydıkları bu performanslar; haz ve şiddeti, iktidar ve öteki olma durumlarının yer değiştirdiği ve kendilerine yönelttikleri merak duygusu ile kendi sınırlarını öğrenmeye çalıştıkları bir yolculuktur. Bedensel eylemlerde bir kimliği işaretlemekten daha çok kimliği gerçekleştirmeleri açısından etkili olan performans disiplini sonuçları süreçle gelişen bir durum ortaya koymaktadır (Lichte, 2016,s. 40). 1977 yılında Bolonya, G7 Galeride, on altı saat boyunca sırt sırta oturarak saçları ile birbirine bağlı şekilde, baş başa gerçekleştirdikleri performanslarının son bir saatinde, performans izleyicinin katılımına açılmıştır. Her saat başı fotoğraflanarak ve kamera kayıtları alınan performans, bedenlerin zaman içerisinde yaşadıkları çözülmeyi kademe kademe göz önüne sermektedir. İlkin s1k1 ve birbirine düzgün şekilde sarılmış saçları, dik şekilde oturan ve yekpare bir kütleye benzeyen bedenleri (Görsel 4a); zaman içerisinde dış hatları çözünen, değişen, aşınan bir hale gelmiştir (Görsel 4b) Zaman bedenlerin durumlarını, ilişkileri ve zihni değiştiren bir etmendir. Günlük yaşamda kaçırılan bu durum, bir laboratuvar ortamı olarak kullanılan galeri içerisinde steril bir gözlem olanağı vermektedir. Ulay ve Abromovic'in birbirine dolanmış saçları, tek başlı, çok uzuvlu bir beden oluşturmaktadır. Bir saçtan daha çok iki enerji kütlesini birbirine bağlayan bir akış kanalını çağrıştıran saç, performans süreci içerisinde ilerleyen zamanda birlikte, bedenin küçük kıpırdanışlarına bağlı olarak çözülmeye başlamıştır. Kadın ve erkek ilişkilerini, deneyimleri üzerinden aktardıkları performanslarında seyirci, katılımcı değil izleyicidir. Ulay ve Abromovic kendi deneyimlerini bir aynaya çevirmektedir. Toplumdan en küçük ilişki biçimine karşılık gelen bu iki bedenin hali, bir biri içine karışmış beden durumunun sürekliliği, her bir bedenin konumuna, performansına ve on altı saat boyunca orada olma isteğine bağlı olup, ölçüt zamandır. Zaman herkese değmekte ve değdiği her bireyi değiştirmektedir. Performansta sanatçıların bedenlerini birbirine bağlayan saç, romantik bir göstergeden çok biz zorunluğun altını çizmektedir (Wojcik, 2016).

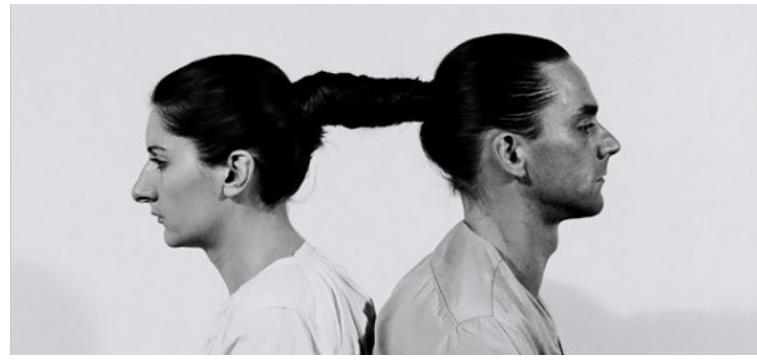

a.

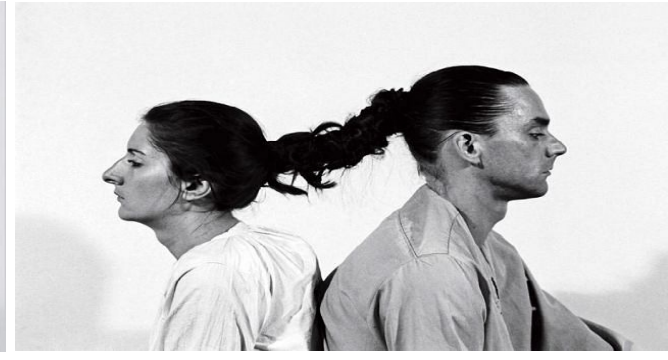

b.

Görsel 4. Marina Abromovic \& Ulay, Zamanla İlişki, 1977

Filistin asıllı Mona Hatoum'un çalışmalarında kimlik sorununu, göç ettiği coğrafyasının bilgilerini içinde taşıyan, ancak bu bilgileri bir görüşte göze getirmeyen, izleyiciyi içine alarak genişleyen ve farklılaşan sınırlarına doğru çekmektedir. Kadın dünyasının günlük yaşam içerisinde çokça kullandığı araç gereçler, onun çalışmalarında bir işkence aletini çağrıştıran heykellere dönüşür; büyür genişler, yutar ve görünmez uçucu bir yokluğun, kaybın ifadesini oluşturur. Artık olmayan bir yuva ve uzakta olan ülkenin yokluğu kendini hissedilir işaretler haline bırakır. Sanatçı, örme ve örme işlemini tersine çevirdiği çözme eylemlerini sıklıkla üretimlerine taşıyarak, kuvvetli dişil ifadeler yaratmaktadır. Bağlama, ilmek ve örgü, kadın dünyasının zaman ölçütüdür. "Yunan Mitolojisinde, Penolope için örgü örmek sonu gelmeyen bir erteleme faaliyetidir; kocası Ulysses'in savaştan dönmesini 
beklerken, her akşam gündüz ördüklerini söker ve sabırsız talipleriyle buluşma vaktini sonsuza dek erteler. Örgü örmek birinin geri gelmesini, her şeyin tekrar normale dönmesini sürekli beklemeyi ifade eder" (Bell, 2012, s. 97). Kimi zaman nesneleri ve heykelleri birbirine bağlayan, kimi zaman ise sergi mekânında bulunan saç öbekleri (Görsel 5) Mona Hatoum'un zamanla bedeninden ayrılan kopan, beden ile zaman arasındaki ilişkilerin kuvvetli göstergeleri olarak kullanılmaktadır. 1995 tarihli, 'Hatırlama' adlı yapıtında, sanatçı gerekli malzemeyi uzun yıllar boyunca biriktirmiştir. Saç, yumak haline getirilip koza veya toz topakları gibi hafif, 1şığı geçiren objelere dönüştürülmüş ve mekâna dağılmış, teller halinde tavandan sarkıtılmış ve bir dokuma tezgâhının üzerine bir el işi parçası gibi dokunmuştur.

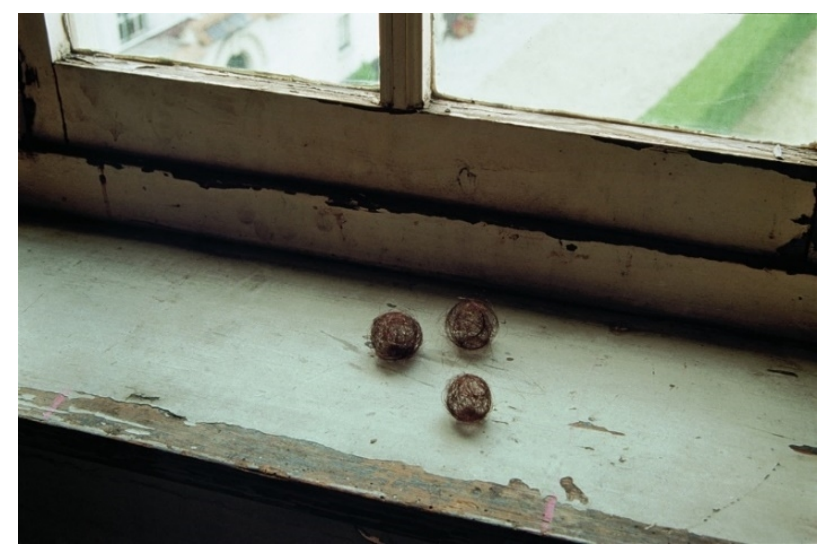

Görsel 5. Mona Hatoum, Hatırlama, 1995

Örmek, Hatoum'un işlerinde tekrar tekrar ortaya çıkar ve ișlerinin merkezi yapılarından biridir. Geleneksel Arap örtülerinden olan ve erkeklerin boyun ve başlarını sarmak için kullandıkları 'Keffieh', Hatoum'un çalışmasında kadın saçları ile dokunmuş bir halde üretilmiştir (Görsel 6). Filistin direnişinin önemli sembollerinden biri olan bu örtü, direnişte gölgede kalan kadınların durumlarını, yaşamdaki konumlarına benzer bir yakınlıkta, örtülü bir ifadeyle eserine eklemektedir. "Hotoum'un çalışmalarında kadın görünürlüğü saç ile özdeş tutulurken, bedenden kesilmiş, sıyrılmış ya da bu coğrafyada acı ve çaresizlik karşısında saçlarını yolan, dövünen bir bedenin uzantısı olarak saç, önemli imajlar barındırmakta ve farklı okuma olanakları sunmaktadır (Parten, 2017, s. 157). Hatoum bu örtüsünde saç kadın bedenini kırılgan tezahürü olarak erkeğin boynuna sarılan ya da o erkek dünyasını boynundan tutup sarsan ucu açık bir okuma sunmaktadır. Sanatçının saç ile üretmiş olduğu bu eserlerinin anlaşılması yakın ve dikkatli bir mesafeyi gerekli kılmakta ancak böylesi bir mesafeden eserler okunur hale gelmektedir. Saç ile örgü örmek, saçı örmekten hem farklı hem de benzer anlamlar arasında bir yerdedir. Görünmesi ve üretilmesi zorlu bir ipe dönüşen bedene doğru ulaşan bir yolun işaretlerini ortaya koymaktadır. Sanatçının ilk dönem çalışmalarında oluşturduğu performanslar içerisinde edindiği beden tecrübeleri, ilerleyen dönem çalışmalarında, bedene yönelen, bedeni imgeleyen, üretimleri ortaya koymasına yardımcı olmuştur. Heykellerinde kullandığı ve minimal sanatın kök formlarından ızgara planlı küp formu, hem demir kafeslerinde hem de saçla oluşturulmuş formlarında karşımıza çıkmaktadır. Farklı teknik ve malzemelerin yan yana duruşları, benzer formun nasıl çeşitlenen bir dil oluşturduğunu göstermesi açısından da ilgi çekmekte ve bir gerilim yaratmaktadır.

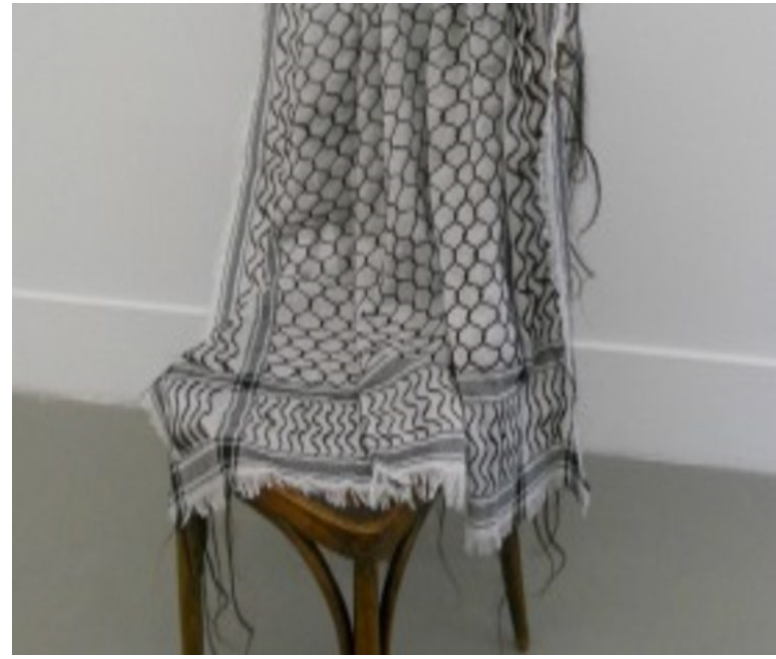

Görsel 6. Mona Hatoum, Keffieh, 1993-1999 
Nezaket Ekici, 1970 yılında Kırşehir'de doğmuş, 1973 yılında Almanya'ya göç etmiş orada yaşamını sürdüren, ikinci kuşak Türk göçmenlerinden biridir. Sanatına göç olgusu ve iki kültür arasına sıkışmış olma durumlarını taşımanın yanı sıra Ekici, çeşitlilik gösteren performanslarında belli konularla kendini sınırlamaktan kaçınmaktadır. Ancak, kadın olma durumları, kültürel politikaların kadın bedeni üzerinde yaşattığı izleri ve sanat tarihinde kadın ifadeleri, sıklıkla gündeme aldığ 1 konular arasındadır. İlya Kabakov ve Maria Abromovic'in öğrencisi olmasının etkileri üretimleri açısından önemlidir (Kirazc1, 2010, s. 18). Performansları için, bedeni ile seyirci arasına bir hayal kurabilme mesafesi yarattığını söyleyen Ekici, bedenini araç olarak kullanmasının yanında performansın izleyicinin önünde gerçekleşmesi, aksi takdirde ortaya konulan çalışmanın performans olarak değerlendirilmemesi gerektiğini savunmaktadır (Ekici, 2012). 2006 yılında I. Sinop Bienali kapsamında, Tarihi Sinop Hapishanesi mekânında gerçekleştirmiş olduğu 'Atrapos' adlı performansımda Ekici, 100 adet beyaz ip ve 100 adet kanca aracılığı ile tavana asılmış olan saçlarını, performans süreci boyunca bu durumdan kurtarmaya çalışmaktadır (Görsel 7).

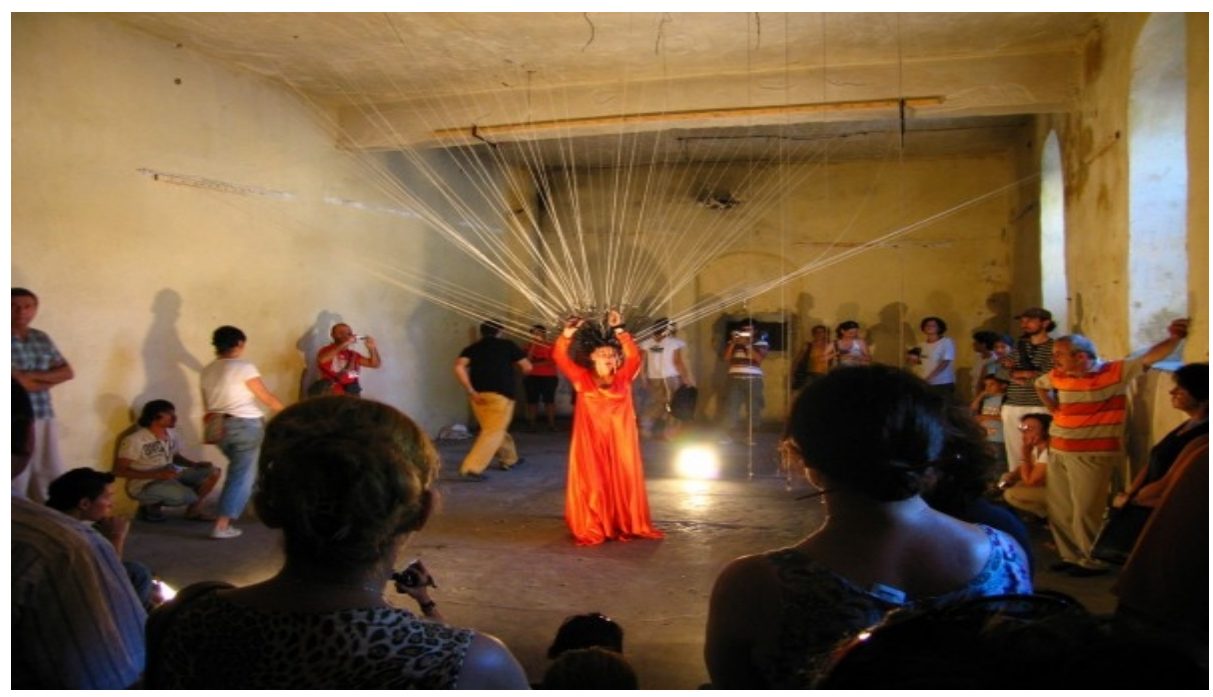

Görsel 7. Nezaket Ekici, Atrapos, 2006

Atrapos, Yunan Mitolojisinde, kader tanrıçaları Moiralar olarak anılan üç kız kardeşten insanların yaşam sürelerini betimleyen ipleri, ölüm zamanları geldiğinde kesen tanrıçaya verilen addır. Nezaket Ekici performansında çok katmanlı bir okuma sunmaktadır. Öncelikle performansın gerçekleştiği mekân uzun yıllar bir hapishane olarak kullanılmıştır. Sanatçı, mekâna asılan saçları ile mekân içerisinde bir sütun ya da duvar resmi gibi, bedeni ile mekânın bir parçasına dönüşmüştür. Bu mekân tutsak olma durumu ile hem mekânın belleğini göze getirmekte, hem de artık orda olmayan pek çok bedenin temsilini yüklenmektedir. Tavandan farklı yönlere asılı olan saçlarına rağmen, yürümeye çalışan sanatçı bedeninin her yeni hareketinde kancalarla asılı saçları yüzünden yüz ifadesi farklılaşmakta, bedeni acı çekmekte, bu durumun içinden çıkabilmesi için ise saçlarından vazgeçmesi onları kesmesi gerekmektedir(Görsel 8). Bu durumda bedenin hali, mekândan kurtulmak adına, mekâna bir parçasını bırakarak ilerlemektedir. Beden mekânın tecrübesini kazanırken, mekânda bedenin izini taşımaktadır.

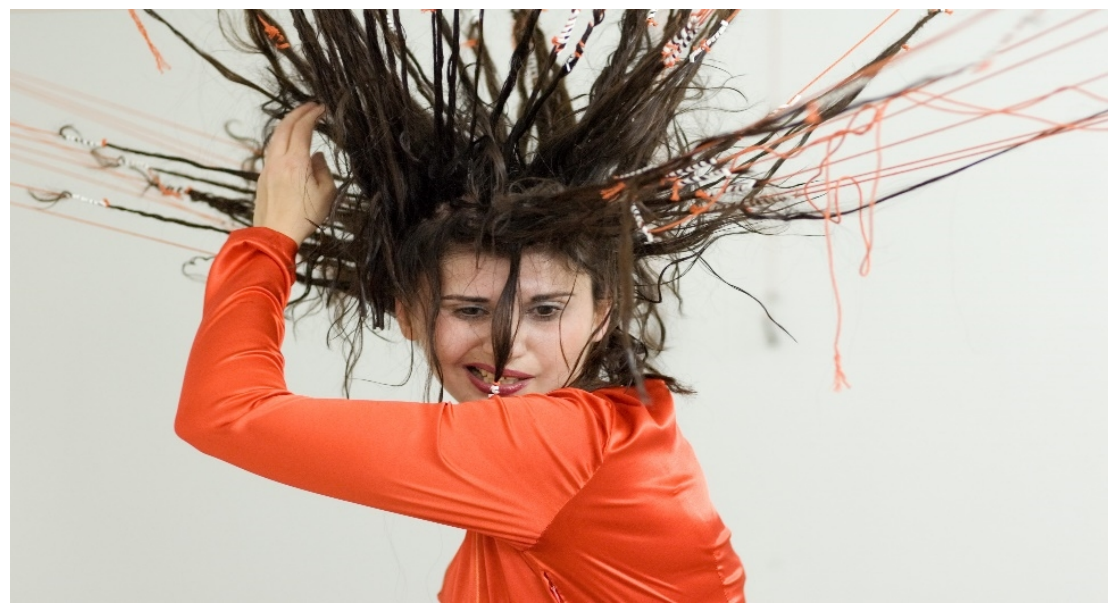

Görsel 8. Nezaket Ekici, Atrapos, 2006 
Ekici kendi kaderini kendi belirlemeye çalışan, hem tutsak hem de tanrıça olan düalist bir duruma getirdiği bedeni üzerinden; kadın, özgürlük, yazgı ve mücadele gibi güçlü kavramları saçları üzerinden aktarmaktadır. Sanatçının seçtiği kıyafetin rengi şiddeti ve tutkuyu hatırlatan kırmızıdır. "Ekici’nin, performanslarında kostüm çok önemlidir. 'Performanslarda giyeceğim kıyafeti önemsiyorum, çünkü elbise benim ikinci bedenimdir' diyen sanatçının her performansı, o performans için seçtiği kıyafetin, ortaya çıkardığı kavramla yakın bir biçimde ilerlemektedir (Arslan, 2020, s. 50).

Khadija Baker, 2009-2012 yılları arasında farklı coğrafyalarda tekrarladı̆̆ı ve video kayıtları ile gösterime sunduğu eserini, savaş ve kadın üzerinde yaşanılan, bedensel ve ruhsal tahribatı saçları üzerinden oluşturduğu performansı ile aktarmaktadır (Görsel 9). Suriyeli sanatçı, Damascus'da tamamladığı sanat eğitiminin ardından, Kanada'ya yerleşmiş ve eserlerini göç ettiği bu coğrafyadan sürdürmeye devam etmektedir, Ancak her göç eden insan gibi, hafızasını; dilinde, masallarında ve küçük objeler üzerinden sürdürmekte, bedenini savaş gören bir coğrafyanın bilgisini aktaran bir hafıza mekânına dönüştürmektedir. Baker, sessizce oturduğu bir kaide üzerinden, doğu coğrafyasında kadınların sıklıkla kullandığı, ince şeritler halinde örmüş olduğu saçları, performansının güçlü bir unsurudur. Khadija Baker, öyküsünü, ya da başkalarından dinlediği öykülerini, lirik bir ses tonu ve vurgulu lehçesi üzerinden, saçının örgüleri arasına yerleştirilmiş küçük kulaklıklar aracılığı ile aktarmaktadır. Saç örgüleri üzerinden izleyiciye akan anılar, büyük politikalar ya da güçlü ideallerden uzaktır (Bakçay, 2013). Kablolar ile örülen saçlarının her biri farklı bir öyküye açılan bir iletken, bir dil görevini üstlenmektedir. Tek bir bedenden farklı öykülere açılarak genişleyen saç örgüleri ile Baker, farklı savaşların ve farklı coğrafyalarda yaşanılan acıların, etkilerinin kadın bedeni üzerinde değişmez tahribatını, suskun ve eylemsiz oturduğu bedeni ile yansıtmaktadır. Ancak ilgilenen insanlara öyküsünü anlatacak kadar bir güce sahip olduğunun ön kabulü ile başladığı performansı sonrasında, Baker'in performansı, video görüntüleri üzerinden aktarılmakta, performans sırasında katılımcıların işittikleri öyküler, monitör karşısına konulan ve yalıtılmış bir ses düzeneği olan kulaklık üzerinden dinlenilmeye uygun bir kurgulama ile sergilenmektedir.

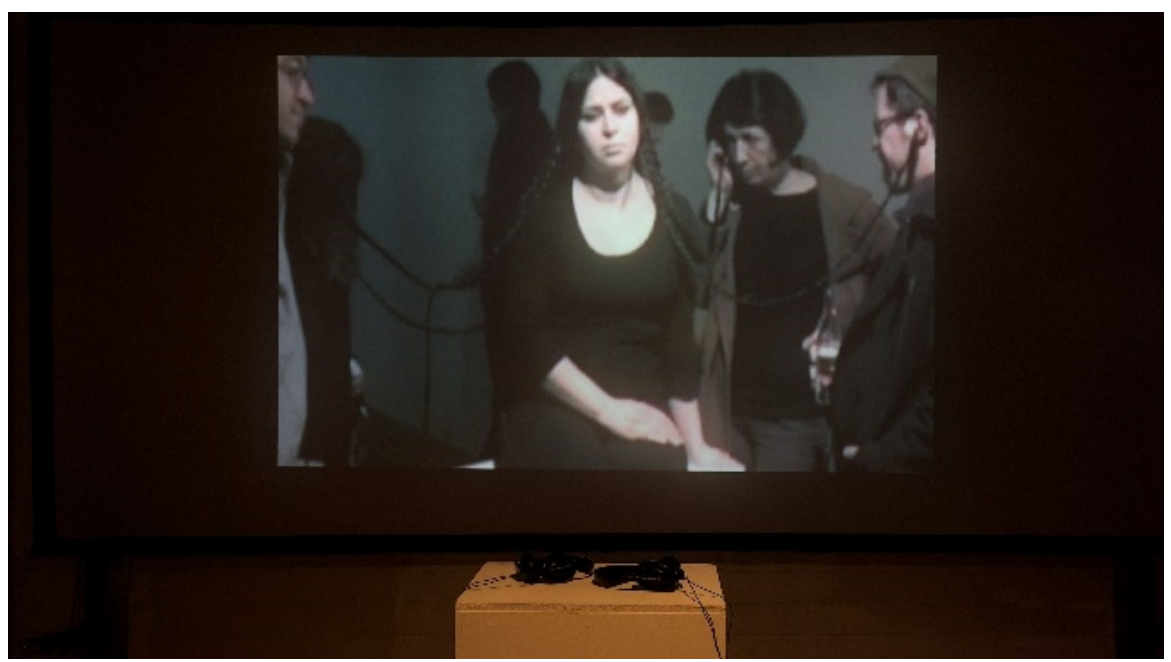

Görsel 9. Khadjila Baker, Küçük Sesim Yalan Söylemez, 2009-2012

Gamze Öztürk, 2018-2019 dönem aralığında, Venedik ve İstanbul kentlerinde bir dizi performans sergilemiştir (Görsel 10). Yaşamış olduğu coğrafyada, hemen her gün işlenen kadın cinayetleri karşısında duyumsadığı tepkiler Öztürk'ü, kadın kahramanların var olduğu ve başkaca kadınların hayallerine ilham olabilmelerini düşlediği bir dünya özlemine doğru sürüklemektedir. Ancak Gamze Öztürk, bir yakarmanın ötesinde, geriye bakıldığında bu coğrafyada, Neolitik dönemlere uzanan ve anaerkil dönemi içine alarak gelişen, güçlü kadın imajlarının varlığını hatırlatılarak tekrar dolaşımda tutulmasının, yaşanılan kötücül durumları bertaraf edeceği inancını taşıdığı ve bedeni üzerinden bu kadın imgelerine uzanmayı amaçlamaktadır. Böylelikle bedenini bu konuya seyirci olma durumundan kurtarmış olduğunu da belirtmektedir. Öztürk, kadınların çocuk doğurmadan, yemek pişirmeye, hamur yoğurmadan acı çekmeye değin çok farklı alanlarda edindikleri tecrübeleri birbirlerine aktarma konusunda gerçekleştirdikleri başarılı hafıza zincirini, günümüz toplumsal koşulları içerisinde, kendi bedensel güçlerinin ortaya çıkarması alanında da uygulamalarını önermekte ve bunun için ise sanat eylemini öne sürmektedir. Son dönem performanslarında sanatçı, bedenini henüz gömü altından çıkarılmış bir buluntu nesneye, primitif bir idol formuna yakınlaştırmak için, boyamakta, kimi uzuvlarını sarmakta baskılamakta örtmekte, kimilerini ise ortaya çıkararak; bedenini soyut bir forma yaklaştırmaktadır. 


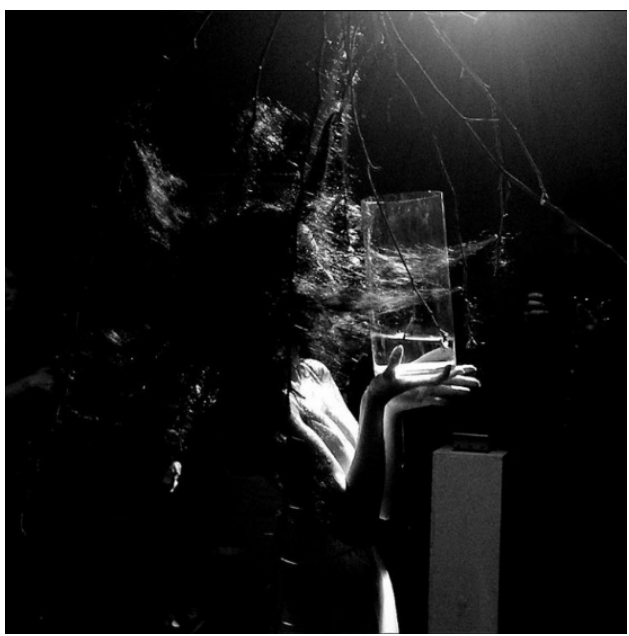

Görsel 10. Gamze Öztürk, Bugünü Oluştur/ Yarını Oluştur, 2019

Şaman, tanrıça, savaşçı, ebe, genç ve artık çok yaşlı olabilecek bir beden soyutluğuna yaklaştığını duyumsadığı zaman, performanslarını gerçekleştirebilen Öztürk, Ağustos 2019'da İstanbul'da faaliyet gösteren Galeri Mod'da sergilediği son performansında, bedeni ile kökü galeri tavanında asılı halde sarkan ağaç dallarına saçlarını bağlayarak, kendini bir ahlat ağacına çevirmiştir. Anadolu'da dilek ağaçlarına verilen bu isim, sanatçının kadın dünyasının huzura kavuşması adına performansında bedenini; dilek dilediği, ektiği, köklendirdiği ve yaşattığı bir ağaca dönüştürmektedir. Bu ahlat ağacı, kökü dışarıda olma hali ile göçebe, her yöne kaçan saç dalları ile değdiği her bedende köklenebilme ihtimalleri ile sonsuz iletişim içerisindedir. Deleuze'ün 'kök-sap' tanımlamasını anıştıran bu beden formu, kendi içine döktüğü su ile beslenmekte ve bu yetkinliğiyle, kadın dünyasının kadın sorunlarının üstesinden geleceğinin işaretlerini göstermektedir. Pek çok sanatçının bedenden uzanan saçları ile mekânı ve cisimlere ulaşmasına benzer süreçleri, başkaca kuvvetli anlamlar oluşturarak ele alan Gamze Öztürk'ün imgeleri, primitif zamanlara olan vurgusunu performansları boyunca izleyicisine hissettirmekte, bir şaman kadın geleneğine eklemlenmektedir.

\section{Sonuç}

Kadınların hemen her alanda vermiş oldukları mücadeleler, kadın sanatçıların kadın bedeni ve toplumsal cinsiyetçiliği aşındıran eserleri, 1960 sonrası yükselen özgürlükçü politikaların ivmesi ve felsefede feminist filozoflarla birlikte kadın kavramları ve bedenleri üzerine yapmış olduğu çalışmalar etkili olmuştur. Kadın fillozofların üretmiş oldukları felsefelerin yanı sıra, felsefede kadın anlamlarının tartışmaya açma olasılıklarını çoğaltan; Derida, Foucault ve bu çalışmada yeni bir düşünme biçimi getirmesi açısından ele alınan Deleuze'ün feminist düşünce sistemine etkileri büyüktür. Kadınların sanat tarihinde, kendi ifadelerini ortaya koymaları açısından bedenlerine yönelmeleri, sanat tarihinin en güçlü imgelerine de yönelmeleri anlamını taşımaktadır. Tüm bir sanat tarihi kadın bedeni üzerinden bir dünya kurgularken, bu zemin kadın sanatçılar tarafından sarsılmıştır. Böylesi bir itirazı geliştirebilmek için, kendi bedenlerinin kök ifadelerini kullanmaları, eril ifadeler içerisinden kadın bilgi ve deneyimlerini, sıyırmaları gerekli görülmüştür. Kadınların, mitolojiden antropolojiye, günlük yaşam pratiklerinden, aynanın karşısında baktıkları bedenlerine değin geniş ve bir o kadar öze inebilen hareket kabiliyetlerini geliştirmeleri, katı halde geleneksel kurum ve düşünceleri sarsabilmelerini sağlamıştır. Bugünün sanat anlayışında, disiplinlerarası üretimlerde ve bedenin izlerini taşıyan yeni malzeme seçkileri ile kadın dünyasının son derece usta olduğu örme, biçme, dikme gibi tekniklerle sanat yapabilmeyi olanaklı hale getiren kadın sanatçılar, aynı zamanda bedenleri üzerinden sarsıcı imajlar oluşturmayı başardılar. Koşarak, bağırarak, durarak, bekleyerek, dokunarak ve kimi zaman kendilerini yaralayarak, kendi tecrübeleriyle yeni kadın imgeleri yarattılar. Bu çabalar arasında, bedenin bilgi ve durumunu, izler üzerinden yürüyerek; ekleyerek ve çıkararak bir heykel gibi kendi bedenlerini şekillendirme konusunda başvurdukları imgeler arasında saç çokça başvurulan ve geniş ifade olanakları sağlayan önemli bir unsur olarak karşımıza çıkmaktadır. Primitif dönemden, mitolojiye, tek tanrılı dinlerden, coğrafyalara, değişen dönüşen, örtülen hallerinin yanı sıra, kadın kimliklerinin en basit ifadeleri olarak açığa çıkmakta, belirmekte ya da algılanmaktadır. Saç, azalan, bağlanan, çoğalan, kesilen ve bir iplik gibi kullanılan yapısıyla, kırılgan, görünmez ve geçirgen olabildiği gibi; örtücü, güçlü ve bedenden kopan, mekâna yayılan lineer çizgiler yaratabilmekte, bedenden ayrılıp, zaman içinde yenilenebilme unsurları ile sanatçılara çeşitli olasılıklar sunması açısından da tercih edilmiştir. En yalın ifade hali ile saç, kadın dünyasının kadim bir zaman çizelgesidir. Ortaya konulan sanatçı seçkisi, kadın bedeninin sanatsal ifadelerinin çoğalmasında, beden performanslarını saç üzerine temellendiren, farklı dönem ve coğrafyalarda yer alan, minör ve kadın oluş kavramlarını ele almaları açısından Deleuze felsefesi ile ilişkiler barındıran bir sanatçı seçkisi üzerinden aktarılmıştır. Kadın bedeni ve onun en güçlü simgelerinin başında gelen saç, primitif dönemden günümüze değin 
politik bir ifade olup, kadın sanatçıların tarihsel ve kültürel kodlara dayanarak ya da karşı çıkarak, saç üzerinden sanatta yeni ve sarsicı kadın ifadelerini performatif eylemlerle ortaya koymaktadır.

\section{Kaynakça}

Abramovic M. (2015). TED konuşması: güven hassasiyet ve bağlamdan oluşan sanat. Erişim Adresi: https://www.ted.com/talks/marina_abramovic_an_art_made_of_trust_vulnerability_and_connection?languag $\mathrm{e}=\operatorname{tr} \# \mathrm{t}-225426$

Antmen. A. (2010). 20.yüzyılda batı sanatında akımlar. İstanbul: Sel Yayınlar1.

Arslan, T. (2020). Bedenin doğası: Nezaket Ekici, sanat dünyamı, performansın dönüşümü. İstanbul. Y.K.Y yayınları. Sayı 174, s:48-55

Bakçay. E. (2013). Barışın görsel dilini konuşmak mümkün mü? Erişim Adresi: https://www.artfulliving.com.tr/project/2430/barisin-gorsel-dilini-konusmak-mumkunmu

Bell K. (2012). Mona Hatoum için bir haritalama denemesi. İ. Baliç (Ed.), Hala buradasın (s. 92-99) içinde. İstanbul: Arter Yayınları.

Berktay, F. (2009). Feminist teorinin önemli bir alan1: Cinsellik. Cogito-Feminizm, 58, 57-73.

Beydili, C. (2005). Türk Mitolojisi Ansiklopedik Sözlük. Ankara: Yurt Yayınları

Carlson, M. (2013). Performans. Ankara: Dost Yayınlar1.

Chanter, T. (2009). Psikanalitik ve post-yapısalcı feminizm ve deleuze, Cogito-Feminizm, 58, 93-127.

Cıbıroğlu, Y. (2017). Kadın saçı büyü ve “türban”. İstanbul: Payel Yayınları.

Direk, Z. (2009). Simone de beauvoir:abjeksiyon ve eros etiği. Cogito-Feminizm, 58, 12-36.

Ekici N. (2012). Bedeniyle hayal kuruyor. Erişim Adresi: http://www.cumhuriyet.com.tr/haber/diger/389028/ Bedeniyle_hayal_kuruyor.html

Erhat, A.(1996). Mitoloji sözlüğ̈̈. İstanbul: Remzi Kitabevi.

Gatens, M. (2001). Güç, bedenler ve farkl111k. Felsefe Logos, Feminist Felsefe, 15, 65-79.

Gatens, M. (2018). Imgesel bedenler etik güç ve bedensellik (D. Eren, Çev.). İstanbul: Otonom Yayınları.

Gillespie, D. F. (2006). Godiva still rides: Virginia Woolf, divestiture, and three guineas. H. Southworth ve E. K. Sparks (Ed.), Woolf and the art of exploration (s. 2-26) içinde. Clemson, SC: Clemson University Digital Press. Erişim adresi: https://tigerprints.clemson.edu/cgi/viewcontent.cgi?article=1003\&context=cudp_ woolfe

Grimal, P.(1997). Mitoloji sözlüğü Yunan ve Roma. İstanbul: Sosyal Yayınları Sözlük.

Grosz, E. (2009). Feminizm, sanat, Deleuze ve Darwincilik, Cogito-Feminizm, 58, 131-144.

Güzel, F. (2018). Gangra (Çankırı) sinodu. ÇKÜ Sosyal Bilimler Dergisi, 9(2), 96-109.

Kirazcı, A. (2010). Bir Nezaket ekici sergisi bağlamında performans sanatına genel bakış. Marmara Üniversitesi Güzel Sanatlar Fakültesi Sanat Tasarım Dergisi, 1(1), 15-23.

Koç, D. (2018). İngiltere ve Fransa'da kadınların saç politikaları ve saç güzelliği algıları (19. yüzyıl'dan 20. yüzyıl'a). Journal of Social And Humanities Sciences Research (JSHSR), 5(22), 870-877.

Lichte, F. E. (2016). Performatif estetik (T. Acil, Çev.). İstanbul: Ayrıntı Yayınları.

Parten, A. (2017). Çağdaş sanatta bir imaj olarak Ortadoğu (Yayınlanmamış Doktora Tezi). Kocaeli Üniversitesi Sosyal Bilimler Enstitüsü Plastik Sanatlar Ana Sanat Dalı, Kocaeli.

Ravaglia, V. (2016). Berlin exercises: Dreamingunder water. Erişim Adresi: https://www.tate.org.uk/art/ artworks/horn-berlin-exercises-dreaming-under-water-t07625

Stark, H. (2018). Deleuze'den sonra feminist teori (Y. Cingöz, Çev.). İstanbul: Otonom Cadı Kazanı Yayınları.

Wojcik. N. (2016). Blood and pain: Extreme performance artist Marina Abramovic turns 70, Erişim Adresi: https:// www.dw.com/en/blood-and-pain-extreme-performance-artist-marina-abramovic-turns-70/a-36583787

\section{Görsel Kaynakçası}

Görsel 1. Göbeklitepe. Erişim Adresi: https://www.researchgate.net/figure/Goebekli-Tepe-engraving-of-afemale-person-from-layer-II-foto-Dieter-Johannes-DAI_fig5_270030960 
Görsel 2. Horn, R. (Sanatçı). (1974). İki Makasla Aynı Anda Saçları Kesme. [Performans ve Video]. ErişimAdresi: https://i.pinimg.com/originals/94/f0/bd/94f0bd679526d8f4583317132e339312.jpg

Görsel 3. Abromovic, M. (Sanatçı). (1975). Sanat Güzel Olmalı Sanatçı Güzel Olmalı. [Performans ve Video]. Erişim Adresi: https://lise.tabella.org/2019/09/01/sanatci-ve-saci-okul-ve-kurali-gelecegin-sanatcilarininidari-kisitlamalarla-imtihani/

Görsel 4a. Abromovic, M \& Ulay. (Sanatç1). (1977). Zamanla İlişki. [Performans ve Fotoğraf]. Erişim Adresi: https://labirynt.com/marina-abramovic-ulay/

Görsel 4b. Abromovic, M \& Ulay. (Sanatç1). (1977). Zamanla İlişki. [Performans ve Fotoğraf]. Erişim Adresi: http://wyborcza.pl/517541020736753.html?i=0\&disableRedirects=true

Görsel 5. Hatoum, M. (Sanatçı). (1995). Hatırlama. [Enstelasyon]. Erişim Adresi: http://ensembles.mhka.be/ items/3846/assets/17805

Görsel 6. Hatoum, M. (Sanatçı). (1993-1999). Keffieh. [Pamuklu kumaş ve Saç]. Erişim adresi: https://lepetitjournal. com/istanbul/a-voir-a-faire/you-are-still-there-mona-hatoum-en-solo-la-galerie-arter84454

Görsel 7. Ekici, N. (Sanatçı). (2006). Atrapos. [Performans ve Fotoğraf]. Eriş̧im Adresi: https://sinopale.org/ gallerypage/

Görsel 8. Ekici, N. (Sanatçı). (2006). [Performans ve Fotoğraf]. Erişim Adresi: Atrapos http:/www.banucarmikli.com/wp-content/uploads/2013/12/Atropos-photo-by-stefan-Erhard1.jpg

Görsel 9. Baker, K. (Sanatçı). (2009-2012). Küçük Sesim Yalan Söylemez. [Performans ve Video]. Erişim Adresi. http://www.artfulliving.com.tr/project/2430/barisin-gorsel-dilini-konusmak-mumkunmu

Görsel 10. Öztürk, G. (Sanatçı). (2019). Bugünü Oluştur/ Yarını Oluştur. [Fotoğraf]. Engin Güneysu tarafından Fotoğraflanmış Sanatçı Albümü. 